\title{
The Missing Politics of Muscular Liberalism
}

\author{
Jan Dobbernack, School of Social and Political Sciences, University of Lincoln*
}

\begin{abstract}
The article examines the idea of muscular liberalism, first invoked by David Cameron as a paradigm of assertive policy-making in opposition to "state multiculturalism". The rhetoric of muscular liberalism is present across Western Europe, but its political effects have not been convincingly explored. In scholarship on ethnic minority integration, a "stimulus-response model" credits Muslim intransigence as the trigger for the muscular stance. Other commentators put muscular liberalism into a genealogical perspective, but do little to consider the circumstances of its political deployment. Working towards an alternative account, the article examines two instances of muscular liberalism in Britain: the campaign against "Sharia Courts" and the "Trojan Horse" affair. Different from the concern with historical continuity or stable potentials of liberal normativity, it draws attention to political operations and strategic calculations that characterize the deployment of muscular liberalism in British politics.
\end{abstract}

Keywords: political liberalism; Sharia courts; Trojan Horse affair; British Muslim politics; liberal genealogy; political realism

\section{Introduction}

Coining a theme for his government's approach towards Islamic extremism, David Cameron proclaimed the need for muscular liberalism in February 2011. After several years, an election and disputes about integration, education and free speech, it is difficult to see a coherent programme that would follow the muscular bent. Policy initiatives in the area of "minority integration" convey a sense of vacuity (DCLG 2012; Cameron 2016). The government's message in the aftermath of terrorist incidents appears conflicted (e.g. Pickles 2015), and the legislative response, leading to the Counter-Terrorism and Security Act 2015, mired in controversy about the justifiability of measures and their implementation. A recent request for Muslim women to improve proficiency in English was framed in terms of assertiveness "about our liberal values" (Cameron 2016) in the struggle against Islamic extremism. As in other cases, sweeping statements about the defence of liberal values often seem disconnected from specific policy measures - here: some adjustments to the spousal visa regime - that purport to achieve liberal ends.

\footnotetext{
${ }^{*}$ Forthcoming in Identities.
} 
The record of muscular liberalism is mixed. The Coalition between Tories and Liberal Democrats government has arguably adopted some measures, notably where security concerns prevail and when conflicts are framed in civilizational terms, that showcase a muscular stance towards British Muslims. After the 2015 election, there are some signs that the Conservative government has stiffened its response, with a leading role for security agencies even where international or domestic security concerns would seem tenuous (e.g. Home Office 2015; Cameron 2016). Yet there is little indication of government's willingness to invest significant resources into muscular policy-making. Rather than part of a coherent framework, muscular measures often seem clumsy, contradictory and contested. They are usually qualified by references to right-wing extremism and Islamophobia that are said to also require monitoring, as well as by a commitment to not criticize or attack "the religion of Islam or its followers" (Home Office 2015, 6). The significance of muscular liberalism for the British state's engagement with its Muslim populations is in need of some clarification.

The concern with this article is to work towards a clearer view. Muscular liberalism may have experienced limitations as a result of being caught up in political disputes. It may have been qualified where it contradicts non-muscular commitments or fails to attract popular support. But irrespective of such limitations, it is uncertain what type of effects we should expect muscular liberalism to have, and both mainstream and critical perspectives on the Muslim presence in the liberal state have not been particularly helpful in suggesting an answer. Two types of responses - discussed here as stimulus-response and liberal genealogy - underpin recent scholarship and draw attention to the normative structure of the liberal state and historical repertories of liberalism. Taking issue with the neglect of power, interest and political positioning in both perspectives, my argument is that muscular liberalism is best understood as a matter of politics.

Two recent episodes in the British state's engagement with Muslims serve to spell out why the absence of politics matters. The first is the attempt by a member of the House of Lords, Caroline Cox, to curtail the operation of Islamic arbitration tribunals and mediation services ("Sharia Courts"). Drawing on support from pressure groups and in parliament, Cox introduced a Private member's bill to tighten the regulatory framework for arbitration 
tribunals. With the Coalition government in place until 2015, its adoption seemed unlikely as the official commitment to muscular principles, supporters of the bill remarked, left to be desired (Cox 2011; Waters 2013). More recently, then-Home Secretary, Theresa May, has promised to initiate an investigation into how "Shari'a is being misused and applied in a way which is incompatible with the law" (Home Office 2015, 12).

A second episode that attracted attention in 2014 raises similar questions. In the "Trojan Horse" affair, Muslim educationalists stood accused of "infiltrating" Birmingham schools. Although charges were revealed to be overblown (see House of Commons 2015, 9-10), they did not collapse but shifted from accusations around "extremism" to the claim that insufficient attention had been paid to the promotion of "British values". The sticking point became that "children are not being encouraged to develop tolerant attitudes towards all faiths and all cultures" (Wilshaw 2014). Cameron (2014) proclaimed the "need to be far more muscular in promoting British values" and this request informs a new domain of educational monitoring. The promotion of "British values" has since become a vehicle for government's engagement with British Muslims, often by mobilizing subordinate institutional actors that assume responsibility for safeguarding and surveillance.

The episodes provide useful material to explore assumptions about muscular liberalism in British politics. After reviewing the relevant rhetoric and commenting on two strands in the literature, the article outlines elements of a politically engaged perspective on muscular liberalism, which owes to contributions by Bonnie Honig $(1993,2009)$ and Raymond Geuss (2001, 2008). It concludes with a discussion of muscular liberalism in the context of normative positions, mediatized representations and political practices that surround the presence of Muslim populations in Britain.

\section{Muscular rhetoric}

In 2011, Cameron delivered a speech on muscular liberalism at the Munich Sicherheitskonferenz, an annual meeting of politicians, national security experts and the arms industry (Cameron 2011; see Klug (2011) for an excellent rhetorical analysis). The Prime Minister set out by announcing that despite cutbacks Britain was not "retreating from an activist role in the world". He went on to develop themes from within domestic debates on 
"radicalisation" and endorsed the notion of a spectrum of troublesome positions among British Muslims, ranging from those who show "real hostility towards Western democracy and liberal values" to others who embark on violence. Mirroring the disavowal of retreat in global politics, muscular liberalism meant confronting extremism in all its forms.

Cameron's other central message was that it had become "hard to identify with Britain [...] because we have allowed the weakening of our collective identity". The "doctrine of state multiculturalism" had encouraged segregation and there was no "vision of society" to which young Muslims feel they could belong. Minority status and political correctness had shielded Muslim communities from criticism for their illiberal practices. Extremist ideologies should be confronted and there should be "a clear sense of shared national identity that is open to everyone".

The speech attracted interest as it seemed to indicate a new approach in the risk management of British Muslims. It committed the government to the "conveyer belt" view of radicalisation, positing the continuity between "violent extremism" and "non-violent extremism". It seemed to suggest a less cooperative stance towards Muslim organisations and hinted at more restrictive policies in the area of minority integration.

Elements of muscular rhetoric have been present under the previous government (McGhee 2010). Labour policy instrument persist, in particular the Prevent agenda of counter-extremism that has re-emerged as a vehicle for engaging Muslims in the aftermath of the "Trojan Horse" affair. Muscular politics, then, draws on precedents, which does not change the fact that it presents itself as a novelty and the departure from "failed policies of the past", collectively captured under the rubric of "state multiculturalism" (Cameron 2011).

Rhetorically, the Prime Minister's claim to novelty was borne out by emphasis on gender equality, freedom of speech and the rule of law, which he pointed to as principles according to which Muslims, individually and collectively, would be judged. The speech offered a more direct attempt to specify British national identity by way of a contrast with "radical Islam". While the previous government had also sketched out "Britishness" in relation to alleged failures of minority integration, the threat associated with the presence of Muslims in Britain 
has become more closely and conditionally linked to a canon of national values (Cameron 2014).

Elements in Cameron's Munich speech, which re-emerge periodically since 2011, bear resemblance to high-level rhetoric across Europe that credits liberal timidity and political correctness with blame for significant social problems. In the 1990s, the Dutch Premier, Frits Bolkestein (1991), demanded "liberalism with guts". Requests to re-fashion liberalism in order to cope with Islamic radicalism have since been a feature of conversations about European Muslims. Cameron's muscular liberalism forms part of a tendency, then, that bears out a myriad of speech acts on the place of Muslims in the liberal state. The concerned interventions request compliance with liberal values - or at least aim to be reported as such.

As suggested, there are two frames available for putting muscular liberalism into an explanatory perspective:

A common description credits Muslim intransigence, which is said to bear out to a hardline, civic-universalist response. Challenged by far-ranging requests for religious accommodation, European states fortify their citizenship regimes and embark on new projects of liberal exclusion. Muscular liberalism emerges from within, or at least is a byproduct of, the confrontation between self-doubting liberalism and confident Islam. Elements of this position are present in strands of the literature that treat Muslim claimsmaking as exceptionally challenging or that review changing national models of minority integration, which are said to be uniquely responsive to Muslims' alleged intransigence.

A different perspective situates the same transformations among similarly far-ranging operations, yet locates these, for example, as part of the "channelling of aversion" (Brown 2006) in the liberal state. The protection of "dominant liberal norms and values against illiberal forms of life" (Lentin and Titley 2011, 88) underpins new projects of exclusion that are conducted in a liberal mode and in continuity with older mechanisms of imperial and racial ordering.

The article sets out by questioning the first perspective, which obscures political dynamics by focusing on stable repertories of contention that are said to respond to illiberal 
stimuli. By contrast, the second frame - correctly, in my view - draws attention to dynamics situated at home: within the liberal state and among its individual and institutional proponents. Yet its emphasis on macroscopic analysis makes it less helpful where the circumstances of muscular liberalism need to be explored. The perspective developed and applied in this article is distinguished by a preference for politics that is missing in both.

\section{Muslim stimulus/muscular response}

The main argument advanced by supporters of this view is that, after the failure of multicultural-corporatist models of minority integration, the Muslim presence poses a challenge that culminates in the muscular stance. Accounts of Muslim intransigence, on the one hand, and muscular tendencies inherent in liberalism, on the other, both merit more detailed scrutiny. The following, however, merely needs to be concerned with explanations that draw a connection between the two.

Echoing a well-known critique of cultural rights, Randall Hansen (2011), for example, recommends the "privatization" of difference as the appropriate understanding of the liberal tradition. The prescription he endorses is exemplified by two country cases: the United States' commitment to markets and the French insistence on "universal national values" $(2011,885)$. The suggestion that follows is that flexible labour markets and minimal welfare regimes incentivize work, prevent dependency, activate minority populations, and in doing so outperform their corporatist counterparts. The French case - illustrated by survey data on attitudes among European Muslims - is said to show that integration succeeds "when the receiving countries have a clear integration framework reflecting confidently held values" $(2011,894)$.

Hansen pitches his preference for social minimalism and moral republicanism, at least where ethnic minority populations are concerned, in relation to one of "two faces of liberalism", the one he associates with "tough love" $(2011,888)$ rather than liberal permissiveness. Problems that become associated with the Muslim presence in Europe are accounted for in the terms of a stable antagonism with political liberalism, which becomes an explanatory variable in its own right. This antagonism draws on the staging of caricatures on both sides when it contrasts more or less stable normative repertories of (European) liberal 
attitudes against (Muslim) illiberalism, often by drawing on decontextualized accounts of Muslim religiosity and Islam (see also Joppke 2009, Ch. 5; Koopmans 2015).

For the purpose of my discussion, this caricature is not the only problem. The devil also lies in the detail of a definition that sees politics exhausted by the pursuit of normative purposes if it requires serious analysis. For Joppke, the label muscular liberalism is reserved for measures that go problematically far in demanding adherence to a liberal identity (Joppke and Torpey 2013, 153; Joppke, 2014). This would seem to include intrusive lines of questioning in citizenship tests or loyalty oaths that are increasingly found at the endpoint of naturalization procedures and require aspirants to profess their commitment to a national creed. Such attempts are either futile, as they contradict the liberal refusal to monitor subjective beliefs or turn out to be marginal, in that the most interesting developments, including the "death of multiculturalism" that Joppke has variously invoked, occur outside the scope of this definition.

The logic of stimulus-response coincides with the causal story that underpins the rhetoric of muscular liberalism. The "strident statements" of Tariq Ramadan, the scholar of European Islam that Joppke (e.g. 2014, 289) frequently cites with disapproval, or the "distinctly illiberal leanings of organized Islam" (ibid.) that he sees at work in Britain, are among the reasons that, cumulatively, lead to the departure from the "liberal-cummulticultural recipe of a 'passively tolerant society'." This departure becomes understandable as a consequence of the liberal state's encounter with Muslim intransigence. The political change associated with this departure, whether it is defined in the terms of muscular liberalism or not, is brought about by the presence of Muslims among which "reverberates the archaic power of religion" (Joppke 2009, 111; see also Joppke and Torpey 2013, 153). The thickening of liberal precepts, as well as the departure from multiculturalism, become understandable in light of this illiberal stimulus.

\section{Liberal genealogy}

That the muscular phenomenon can be understood as response to the Muslim presence in Europe seems doubtful if only for reasons of historical precedent. In the English-speaking world, liberal nation-building tended to rely on the contrast provided by putatively illiberal 
outsiders. Liberal nativism is neither new nor particularly exceptional, as Hamburger (2002) shows for the United States. Elsewhere, the development of exclusionary policies out of (alleged) crises of political liberalism draws attention to similar tendencies. In the German Kaiserreich, Treitschke $(1881,26)$ - a leading protagonist of nationalist liberalism - traced popular anti-Semitism to Jewish insolence (Frechheit), which had been encouraged by "big words about tolerance and Enlightenment". The illiberal antagonist is a role that has been filled out by changing populations and the accusation of liberal permissiveness for encouraging unreasonable minority demands is a recurring feature in how minority populations have been engaged.

In Britain, for example, there are parallels between muscular liberalism and articulations of a combative disposition in a 19th century context, which have been noticed by scholars concerned with muscular liberalism's genealogy. James Fitzjames Stephen, to select just one example, criticized J.S. Mill's modus vivendi liberalism and achieved some popularity with requests for a "vigorous" re-interpretation of liberal ideas to suit the purpose of colonial administration. For Stephen - a member of the Colonial Council of India in the 1860s - this vigorous alternative was embodied in the suppression of the Indian Mutiny, and the endurance of colonials caught up in it. Their conduct served as template for a "'masculine' conception of liberty - a hardy, strenuous determination to overcome adversity" (Stapleton 1998, 245). Earlier, Stephen (1862) had set out this meaning of liberalism for the challenge of colonial administration: "India is but one instance of the problem which true liberals must solve successfully if their success is to be a blessing and not a curse." The Mutiny, dealing a blow to the notion that the British civilizing mission would be easily accomplished, gave the occasions for this vigorous re-formulation. It also underpinned the parallel development of a "muscular Christianity", to which van der Veer $(2001,84)$ refers as the "propagation of manly virtues, such as willpower, honor, and courage" in the harnessing of a "national and imperial projects".

Gilroy $(2012,385)$ draws attention to this legacy and the "suitably nineteenth-century ring" he detects in muscular liberalism. Cameron's rhetoric "racialises a victorious outcome in the civilisational swirl of contending values on which national security depends" (2012, 389). The establishment of civilizational lines around purportedly liberal values puts muscular 
liberalism into a particular historical perspective. It points to continuities with "Victorian anxieties [that] propelled diverse and often violent projects for controlling the unknown, the threatening, and the potentially disruptive" (Hall 2006, 9). This would seem to be confirmed by scholars that observe how "discourses of liberalism shape racialized exclusion in a postracial socioscape" (Lentin and Titley 2011, 90).

Genealogies of liberal exclusion challenge the view that a uniquely Muslim stimulus would be needed for liberal politics to adopt the muscular mode. But, it appears to me, the circumstances of muscular liberalism and its deployment at particular junctures are difficult to account for genealogically. The relevant repertories of exclusion, significant as they may be, need to be channeled politically to become effective. Both stimulus-response and liberal genealogy, which I have only sketched out here in general terms, run into problems for their displacement of politics.

\section{A preference for politics}

The position that I invoke here owes to critical reflections on related themes, notably to Bonnie Honig's $(1993,2008)$ critique of "virtue theories of politics" and Raymond Geuss's $(2001,2008)$ rejection of "ethics first". Geuss $(2001,69)$ claims that liberalism is by necessity "practically engaged, historically located", with the corollary that its definition will vary in line with contextual circumstances and strategic interests underpinning its deployment. In turn, Honig $(1993,2)$ challenges a restricted view of politics that exhausts itself in "juridical, administrative, or regulative tasks of stabilizing moral and political subjects, building consensus, maintaining agreements, or consolidating communities and identities".

For the case at hand, this means that the multiple considerations that are reflected in, and impinge upon, political and administrative designs towards Muslims in the UK are difficult to put in terms of a coherent ethical orientation. But they are also scarcely possible to grasp, as I will suggest in more detail below, through a historicisation that traces contemporary responses to continuous repertories of exclusion that now express themselves in the terms of muscular liberalism. This does not mean that particular elements or rationales, such as a securitarian logic in the UK's "policed multiculturalism" (Ragazzi 2016), do not prevail at any particular moment. But their prevalence will need to be understood as 
an artefact of political struggles that require due attention to "agency, power, and interests and the relations among these" (Geuss 2008, 25).

It is not difficult to see how this position challenges the view that stable commitments to liberalism, or to one of two liberal "faces", could offer a meaningful account of how European states engage their Muslim populations. The stimulus-response model suggests that the muscular phenomenon can be understood in the context of the liberal state's ethical orientation. It proposes that political change in the form of more assertive civic-universalist policies towards Muslims are "driven by the instinct that it is not enough to agree to liberaldemocratic norms only instrumentally" (Joppke 2014, 293). The notion here is that liberalism is "offended" by the Muslim presence or that Muslim requests cannot be "processed" (Joppke 2009, 109) in the liberal state, which accounts for defence mechanisms that may take the rhetorical form of muscular liberalism.

From this perspective, we would expect stable and continuous pressure where Muslim requests are found to clash with liberal norms; a particular emphasis on the normative incompatibility of religious requests with liberal constitutionalism; and the mobilization of audiences that are noticeably concerned with the integrity of liberal order. Certainly, none of these features would need to be present in an undiluted form, but we would at least expect to find elements of the relevant logics. The following discussion does not "test" these expectations in a narrow sense, but reviews two recent episodes of muscular liberalism to shed light on their plausibility and identify alternative logics.

\section{Sharia Courts}

"Sharia Courts" have been come to be debated in a number of country cases. Despite contextual specificity, debates tend to draw on recurring arguments about gender inequality and women's rights, the supremacy of native law as well as the public insecurity associated with so-called ethnic enclaves. In the British case, it is usually not the existence of minority legal orders, but the terms that are at stake according to which Muslim communities - just like other faith groups - may offer dispute resolution in accordance with religious tenets, notably in the area of family law. Such mechanisms are available in accordance with the Arbitration Act 1996, which allows for the formalization of arbitration outcomes between 
two parties that willingly submit to the relevant procedures in civil matters. The Act creates the possibility of Muslim arbitration but also applies to Jewish Beth Din, Catholic marriage tribunals and various forms of non-religious arbitration (although critics of "Sharia Courts" stress that non-Islamic arbitration does not raise similar issues, e.g. Cox 2015, 10, 37).

The opposition to Muslim mediation and arbitration services, summarily referred to as "Sharia Courts", unites socialist and liberal secularists with mainstream conservatives and neo-conservatives, such as the force behind the bill that is of interest here, Caroline Cox. Cox's career included advocacy on disability rights and against the persecution of Christians abroad as well as an affiliation with evangelical pressure groups and organisations that aim to reveal what they consider to be Islam's oppressive and violent potentials. She is linked with prominent protagonists of the international "counter-jihad" scene, invited Geert Wilders in 2009 to the House of Lords, and considers Frank Gaffney, a leading figure on the international Islamophobic scene, "one of her heroes" (Cox 2011). Such associations have not visibly damaged her perception as a genuine voice of women's rights in the campaign against "Sharia Courts".

Participants in the coalition that rallied behind Cox's initiative have relied in particular on the widely palatable commitment to the supremacy of native law. "One law for all" was the title of a review that the conservative think-tank Civitas, with which Cox is also linked, issued in the aftermath of Rowan Williams' comments on shari'a and English law in 2008. The report highlighted three concerns: it mentioned the questionable nature of voluntary consent in arbitration. Since there was "a good deal of intimidation of women in Muslim communities [..] the genuine consent of women could not be accepted as a reality" (MacEoin and Green 2009, 4). Second, it raised the fundamental inequality for women allegedly enshrined in the Qur'an and, third, the backdrop of "fear" (either of God or due to "the wish to remain in good standing with fellow believers") that underpins religious authority and that make Islam an unsuitable basis for arbitration.

At the second reading of the bill on 19 October 2012, Cox prefaced her intervention by highlighting the two objectives of fighting "religiously sanctioned gender discrimination" and the threat of "rapidly developing alternative quasi-legal system" (HL Deb 19 October 2012 c 
1683). With few exceptions, the argument proposed by those in favour of the Act - including by Cox herself - made reference to harms that vulnerable women and children would suffer as a result of religious arbitration/mediation; to the historical achievements of gender equality that "Sharia Courts" risked undercutting; and to the supremacy of British law, which needed to be defended against the encroachment of an illiberal legal order.

These concerns were combined in ways that made them consistent with distinct positions. In the case of Labour peers, past struggles for equality formed the background for comments by trade unionist peers (e.g. Baroness Donaghy, HL Deb 19 October 2012 c. 16878). Conservatives inserted their positions into a longer horizon of civilizational achievements and the development of English liberties. As the sole Liberal Democrat contributing to the debate, Lord Carlile (a prominent lawyer) argued that communal morality ought not override individual rights (HL Deb 19 October 2012 c.1689). Different from the debate over "Sharia Courts" in the Canadian province of Ontario, the inherent harm of group-based expressions of "culture" did not feature prominently in this debate.

Interventions in the parliamentary debate also did not follow the rhetorical tendency of indignation that tends to be present when similar themes are articulated elsewhere, notably in the press. The terms of parliamentary debate in the House of Lords imposed a filter and Cox herself apparently decided to refrain from emphasizing civilizational themes, which she clearly espouses in different venues (e.g. Cox 2011), in the interest of building a broad coalition. Intolerable harms inflicted upon women and children, as well as the Muslim "takeover" of particular social spaces, were thematically present. But the clear majority of speakers expressed their concerns in different terms. Only Lord Kalms, a peer with inclinations towards UKIP, portrayed the challenge of "Sharia Courts" in terms of a civilizational crossroads, with the question "whether this House and this country have any confidence in their own values" (HL Deb 19 October 2012 c.1702).

The government's response by Lord Gardiner indicated a lack of enthusiasm about the entirety of Cox's bill (HL Deb 19 October 2012 c.1710-4). Dissecting the proposal, Gardiner suggested there was no problem requiring legislative remedy. Already now, gender discrimination, intimidation and violence were impermissible and arbitration outcomes that 
had been obtained on the basis of such injustices would be void. Such outcomes, moreover, were open to review and a number of domains, including criminal acts and some family matters, were and would remain beyond arbitration. Gardiner thus submitted that "[i]ncreased awareness requires changes to society, not changes to the law" (HL Deb 19 October 2012 c.1713). Although Gardiner had to face a number of critical queries from speakers that had rallied behind Cox, his response indicated strong reservations towards the legislation.

This unwillingness is difficult to attribute to a principled ethical stance, as the avoidance of over-regulation in one specific case seemed to underpin government's reluctance to embrace the legislation. The notion that "Sharia Courts" constitute an offence to liberal morality was neither articulated (except for Kalms) nor dismissed, but simply side-lined as the relevant actors, such as Gardiner, did not see much benefit in espousing a muscular position. The opposition to Muslim arbitration in parliamentary debate also failed to confirm stimulus-response expectations. Specific misgivings about tribunals were not couched as concerns over the integrity of liberal order, but expressed in terms of particular worries with the vulnerability of some Muslim women. They were presented not as a defence of liberal civilization, but framed in terms speakers derived from their own particular backgrounds, such as trade-unionist commitments.

After the substantive debate of 2012 , governmental reluctance had initially been confirmed (e.g. HC Deb 13 April 2013, Column 289WH). More recently, Theresa May has commissioned a review into problems with "some Shari'a councils", suggesting "[w]e will never countenance allowing an alternative, informal system of law, informed by religious principles, to operate in competition with [English law]" (Home Office 2015, 12). The direction of this inquiry and its likely recommendations are (at the time of writing) unclear, but its establishment appears to be a concession not to Cox, but to more palatable (and less muscular) advocacy groups. What this reveals, though, is that speeches, editorials and governmental "command papers" (e.g. Home Office, 2015), which coincide with well-timed statements to the press, are more likely to contain elements of muscular rhetoric than can be found in parliamentary debate. The "offence" of Muslim religious practice to liberal order 
hardly accounts for stable pressure that would lead to muscular policy-making when applied to the offending instance. Rather, it appears that political actors and their calculations about messages, arenas and audiences determine how much or how little muscular liberalism there is.

\section{The Trojan Horse affair}

The following considers a second case that helps accounting for the muscular phenomenon. In the "Trojan Horse" affair, Muslim educationalists in Birmingham stood accused of having "infiltrated" state schools as part of an extremist plot. As charges were revealed to lack substance, they shifted from the domain of extremism to the failure of promoting "British values". The shift implied that requests for religious accommodation that had previously been contested without being denounced as dangerous (such as the Muslim Council of Britain's guidance on Muslim children in state schools, MCB 2007), would now be considered as part of "hardline strand of Sunni Islam" and raise "concerns about [children's] vulnerability to radicalisation in the future" (Clarke 2014, 13).

In this case, the re-appearance of the request for a "more muscular [approach] in promoting British values" (Cameron 2014) coincided with new sanctions imposed on educationalists and school trusts in Muslim-majority areas. Schools that had previously been rated "outstanding" were now considered "inadequate" due to their alleged failure to monitor radicalisation and promulgate a newly defined set of British values. Indeed, the head of the Ofsted inspectorate, Michael Wilshaw, had remarked in March 2014 that one of the concerned schools was "doing fantastically well" (cited in Baxter 2014).

On one occasion, Ofsted inspectors criticized schools for advocating - rather than implementing - "polices [sic] such as single-sex swimming lessons" (Ofsted 2014a, 3). The negative grade this school received was further based on the impression that governors were not sufficiently versed in the Government's Prevent programme of counter-radicalisation. This standard has become widely deployed, including towards a nursery school that caters for children up to the age of five (Ofsted 2014b, 3). A number of additional schools were criticized for failing to "'actively promote' fundamental British values of democracy, the rule of law, individual liberty, mutual respect and tolerance of those of different faiths and 
beliefs" (Ofsted 2014c, 3). This is the line that the Department of Education had issued as its first response to the "Trojan Horse" affair and that has since been embraced for the purpose of educational monitoring (DfE 2014).

Among the immediate consequences of the affair is the return to the Prevent programme, which has gained new currency under the guise of child safeguarding policies (Miah 2014). Moreover, "British values", which had been the subject of inconclusive public consultations in the past, have been rapidly delineated. Finally, Muslim requests for educational accommodation have been brought into the domain of dangerous conduct. The reference to Britain as a liberal state, and the ad-hoc definition of what this entails, fuses with concerns about public security. The existing toolkit of counter-radicalisation, endorsed by Cameron (2011) in his Munich speech, has proven capacious enough to encapsulate such concerns and to allow a shift from general muscular rhetoric towards the deployment of muscular procedures in Birmingham and across the British educational sector.

This is exemplified in the major report into the case for which the Department of Education commissioned Peter Clarke, the former head of counter-terrorism at the Metropolitan Police. Clarke $(2014,12)$ committed himself to applying the "spectrum of extremism described by the Prime Minister in his Munich speech in February 2011". Acknowledging patchy evidence, he upheld the view that there had been a conspiracy led by "a number of people, associated with each other and in positions of influence in schools and governing bodies, who espouse, endorse or fail to challenge extremist views" $(2014,12)$. Regarding the field of education, he applied this spectrum - espousing, endorsing or failing to challenge - to delineate new standards of judgment. The failure to "challenge extremist views" (Clarke 2014, 12), for example, could be substantiated with evidence such as the aforementioned preference for single-sex swimming lessons. Clarke $(2014,13,52,95)$ put considerable emphasis on the risk of "narrowing" the curriculum that made it harder for pupils to "question or challenge radical influences" $(2014,96)$. Even if this did not represent a direct "infiltration", the attempt to expand the scope of religion in school life needed to be rejected as it represented an "intolerant and politicized form of extreme social conservatism that claims to represent, and ultimately seeks to control, all Muslims" (Clarke 2014, 48). It 
constituted an "Islamizing blueprint" (Clarke 2014, 50) that would have to be faced off not simply for its offense to liberal values but for the risk to domestic security.

The Clarke report followed narrowly, and quoted extensively, the rhetorical emphasis that Cameron had set in 2011, which does not mean that it has gone undisputed (see, for example, House of Commons 2015). Its findings have been endorsed by the Home Office $(2015,13-14)$ and appear to capture a popular narrative on "radicalization" in Birmingham schools. This narrative now underpins a system of muscular intervention, which makes schools, universities, local authorities and even hospitals responsible for practices of surveillance and the promulgation of British values.

Whilst the public negotiation of "Sharia Courts" points to the significance of political communication, the "Trojan Horse" affair draws additional attention to circumstances of governance. The translation of muscular rhetoric into muscular politics apparently varies, not least depending on policy tools that are available for putting securitarian rhetoric into political practice. The "Trojan Horse" case was amenable to a default mode of engaging social issues, often propagated as a form of participatory governance, but more suitably described as an authoritarian form of network governance, concerned, in this case, with the production of "stakeholder security" (Jarvis and Lister 2010). In education, existing monitoring regimes have been reinforced that delegate responsibility to detect signs of "radicalisation" to a variety of subordinate actors, which also draws attention to a contrast between the two cases presented here. Depending on the outcome of the ongoing inquiry, the regulation of "Sharia Courts" is likely to necessitate either more direct lines of regulatory responsibility or additional engagement with Muslim faith actors, for which the current government has little appetite. In its response to the "Trojan Horse" case, by contrast, government could abstain from direct interference in favour of loosely operationalizing ambiguous standards around "British values". This creates the scope for regulation in which muscular rhetoric, rather than underpinning a programme of direct governmental intervention, informs standards of compliance.

The "Trojan Horse" episode highlights political and institutional conditions for muscular liberalism to be enacted. In fact, there is little evidence for muscular liberalism in British 
policy making where hands-off arrangements are absent, i.e. where measures require implementation in a "command and control" mode, rather than through the responsibilization of subordinate actors and institutions. As in the previous episode, this does not mean that the impact of muscular liberalism is more limited than assumed; after all, the relevant mechanisms of hands-off governance are, if anything, expanding. But it puts into perspective the claim that stable potentials of liberalism, rather than circumstances of politics, require particular attention.

\section{The politics of muscular liberalism}

The shape of governance arrangements that facilitate the implementation of muscular policies thus requires attention as do political arenas into which muscular message are released. The point in the following is to accentuate this role of politics, extend the critique of stimulus-response to liberal genealogy, and flesh out two provisional avenues for political analysis.

To recapitulate, the stimulus-response model draws a connection between the Muslim presence and muscular policies, pointing to liberal normativity (and how it is offended by Islam) as a crucial explanatory resource. The position informs distinct contributions, such as Joppke's $(2010,138)$ observation that "in the wake of Islamic terrorism, toleration liberalism has receded behind a less procedural, more substantive variant of liberalism" or Hansen's $(2011,888)$ prescription of "tough love", which additionally recommends restrictions to welfare provision. The position channels, and is often close to endorsing, key elements of muscular liberalism in political rhetoric, in particular an account of how "state multiculturalism" and "passive tolerance" underpin historical failures of minority integration.

The problem with this position is the staging of caricatures on both sides: decontextualized Muslims enter the stage as the civilizational others against which models of European liberalism can be defined and defended. I have not engaged with such sweeping accounts of Muslim antagonism here, but simply pointed to the mystification of liberalism in stimulus-response scholarship. Alternative approaches are available that unsettle liberal ideas, situate them historically and politically, and explore how liberal meaning can be modulated in response to historical and political circumstances. Talal Asad $(2013,20)$ 
confirms this alternative, pointing to the malleability of normative ideas, when he suggests that liberalism provides a "vocabulary [that] can cover a multitude of sins - and virtues."

Yet scholars in genealogical vein, including Asad, encounter problems that are not dissimilar. The proposal here is, for example, that "the liberal must continually attack the darkness of the outside world that threatens to overwhelm that [liberal] space" (Asad 2003, 59). Although it is certainly the case that a liberal vocabulary can provide resources for this attack, the liberal dictionary itself is not fixed. Genealogical approaches, which situate muscular liberalism among a history of responses to "difference" in the liberal state and draw particular attention to colonial legacies, also point towards stable mechanisms underpinning liberal politics. As argued previously, such perspectives need to be complemented with an interest in political circumstances to avoid the reification that is characteristic for the stimulus-response model.

The semantic flexibility of liberalism and its context-dependence, then, can be the starting point for a study of muscular liberalism that pays attention to circumstances of muscular politics. I have previously drawn attention to circumstances of communication and governance as two areas of concern without which British muscular liberalism would appear difficult to capture.

Regarding communication, the political message that underpins the rhetoric of muscular liberalism in Britain is characterized by persistent references to the failure of past approaches of minority integration. This reference is partially diagnostic, partially strategic, as it singles out antagonists that are assigned responsibility, such as Labour's disastrous commitment to laissez-faire multiculturalism. The consequences of this failure form part of a contrast with a vision of restored national unity. The Home Office $(2015,7)$ thus suggests where "non-violent extremism goes unchallenged, the values that bind our society together fragment". Cameron (2016), reiterating his Munich message, argues that "[i]t's our values that make this country what it is, and it's only by standing up for them assertively that they will endure." The rhetoric of muscular liberalism is characterized by this type of fantasmatic contrast where a "horrific dimension" of social disintegration connects with utopian counterpoints and a "fullness-to-come once a named or implied obstacle is overcome" (Glynos and Howarth 
$2007,147)$. The urgency of muscular rhetoric, then, relies on how the two are brought together: images of social breakdown and disintegration connect to a promise of wholesome national unity. In this vein, the muscular position offers an account of failures and the promise of restoration that stresses the need to overcome constraints - liberal, legal and procedural, derived from excessive cultural sensitivity and the all-pervasive theme of "political correctness". The understanding is that constraints have to be vanquished, taboos broken, values asserted and sovereign control reestablished. On the basis of these elements, the muscular position promises the release from burdens and the unleashing of national energies.

Yet the appeal of this type of muscular communication is likely to vary and muscular messages will be modulated with a view to particular audiences - ramped up, toned down, or replaced with something else, as the mobilization against "Sharia Courts" shows. There are also no good reasons to believe that full-fledged muscular rhetoric will always translate into specific forms of muscular policy-making, and the "Trojan Horse" case points to the dependence of muscular politics on specific governance arrangements. Arguably, arrangements that place the burden of implementation onto subordinate actors are particularly conducive for muscular rhetoric to impact on political practice, at least in the context of contemporary British politics. This corresponds to a mode of governance as "storytelling", where the aim is to shape "the meanings and identities that constitute selfgoverning actors" (Sørensen 2006, 101; see also Dobbernack 2014, 55-56), although there is an authoritarian bent to arrangements that tend to be backed up by the possibility of a "crackdown" if ambiguous standards fail to be met. In summary, the rhetorical substance of muscular liberalism, and how it is tailored to particular audiences, requires attention alongside the governance arrangements that facilitate or impede its implementation.

\section{Conclusion}

The aim with this article has been to cast doubt on the notion, which informs different strands of scholarship, that muscular liberalism could be understood with reference to stable normative potentials or historical repertories of exclusion. My claim is that politics matters and that its displacement risks obfuscating the phenomenon. The political circumstances of 
muscular liberalism, in turn, are open to a variety of explanatory approaches, and this article merely draws attention to elements of an alternative. The mobilization against "Sharia Courts" illustrates how muscular messages are tailored to relevant audiences. The "Trojan Horse" case provides a case in point for the importance of governing arrangements that help explain where muscular rhetoric is more or less likely to underpin muscular policy-making. These perspectives do not exhaust the phenomenon, which is likely to require not one, but a multiplicity of approaches that situate conceptions of liberalism in concrete political and historical circumstances.

There is a wider point to make about the displacement of politics in scholarship on ethnic minority integration in "the liberal state". The mystification of liberalism in literatures that fixate on normative dispositions at the expense of political operations is unhelpful. Beliefs that agents hold, normative or otherwise, matter. But they do not yield effects that could be understood independently from the study of "agency, power, and interests" (Geuss $2008,25)$. In the same vein, liberalism is not merely a domain of historically predetermined patterns but requires the study of contemporary "wars of position". The advantage with this perspective, which owes more to Gramsci $(1992,219)$ than to either Rawls or Foucault, is that it brings multiple potentials into view. As Honig $(2009,81)$ suggests, these will include tendencies that are "demonological and inclusive, particularistic and universalistic, securitarian and willing to take risks". Acknowledging this multiplicity does not mean minimizing the securitarian streak that distinguishes muscular liberalism, but provides better means for challenging it. 


\section{Bibliography}

Asad, T. 2003. Formations of the secular. Christianity, Islam, modernity. Stanford: Stanford University Press.

Asad, T. 2013. "Free Speech, Blasphemy and Secular Criticism." In: Asad, T., Brown, W., Butler, J. and Mahmood, S. (eds.) Is Critique Secular? Blasphemy, Injury and Free Speech. New York: Fordham University Press. 14-56.

Baxter, J. 2014. "Trojan Horse, the Media and the Ofsted Inspectorate." Discover Society. http://www.discoversociety.org/2014/07/01/policy-briefing-trojan-horse-the-media-andthe-ofsted-inspectorate-2/

Bolkestein, F. 1991. "On the collapse of the Soviet Union." Liberal International. http://www.liberal-international.org/contentFiles/files/Bolkestein\%201991.pdf

Brown, W. 2006. Regulating Aversion. Tolerance in the Age of Identity and Empire. Princeton: Princeton University Press.

Cameron, D. 2011. "PM's speech at Munich Security Conference." Number10.gov.uk. http://www.number10.gov.uk/news/speeches-and-transcripts/2011/02/pms-speech-atmunich-security-conference-60293

Cameron, D. 2014. "British values aren't optional." Daily Mail, 15 June. http://www.dailymail.co.uk/debate/article-2658171/DAVID-CAMERON-British-valuesarent-optional-theyre-vital-Thats-I-promote-EVERY-school-As-row-rages-Trojan-Horsetakeover-classrooms-Prime-Minister-delivers-uncompromising-pledge.html

Cameron, D. 2016. We won't let women be second-class citizens. The Times. http://www.thetimes.co.uk/tto/opinion/columnists/article4667764.ece

Clarke, P. 2014. Report into allegations concerning Birmingham schools arising from the 'Trojan Horse' letter. London: House of Commons.

Cox, C. 2015. "A Parallel World. Confronting the abuse of many Muslim women in Britain today." The Bow Group. http://goo.gl/782uJA

Cox, C. 2011. "Speech at David Horowitz's Restoration Weekend in West Palm Beach, Florida." Frontpage Magazine, 21 December. http://www.frontpagemag.com/2011/frontpagemag-com/baroness-caroline-cox-atrestoration-weekend

DCLG 2012. Creating the conditions for integration. London: Department for Communities and Local Government.

DfE 2014. Promoting fundamental British values as part of SMSC in schools. Departmental advice for maintained schools. London: Department for Education. 
Dobbernack, J. 2014. The Politics of Cohesion in France, Germany and the United Kingdom. Basingstoke: Palgrave.

Gilroy, P. 2012. "'My Britain is fuck all.' Zombie multiculturalism and the race politics of citizenship." Identities 19 (4): 380-397.

Geuss, R. 2001. History and illusion in politics. Cambridge: Cambridge University Press.

Geuss, R. 2008. Philosophy and real politics. Princeton: Princeton University Press.

Glynos, J. and Howarth, D. 2007. Logics of critical explanation in social and political theory. Abingdon: Routledge.

Gramsci, A. 1992. Prison Notebooks. Volume 1. New York: Columbia University Press.

Hall, D.E. 2006. "Muscular Christianity: Reading and writing the male social body." In Muscular Christianity: Embodying the Victorian Age, edited by D.E. Hall, 3-12. Cambridge: Cambridge University Press.

Hamburger, P. 2002. "Illiberal liberalism: Liberal theology, anti-Catholicism \& Church property." Journal of Contemporary Legal Issues 12: 693-725

Hansen, R. 2011. "The two faces of liberalism: Islam in contemporary Europe." Journal of Ethnic and Migration Studies 37 (6): 881-897.

Home Office 2014. "A Stronger Britain, Built on Our Values." Speech by Theresa May at the Royal Institute of Chartered Surveyors. London, 23 March 2015. https://www.gov.uk/government/speeches/a-stronger-britain-built-on-our-values

Home Office 2015. "Counter-Extremism Strategy." https://www.gov.uk/government/uploads/system/uploads/attachment_data/file/470088/ 51859_Cm9148_Accessible.pdf

Honig, B. 1993. Political theory and the displacement of politics. Ithaca: Cornell University Press.

Honig, B. 2009. Emergency politics: paradox, law, democracy. Princeton: Princeton University Press.

House of Commons 2015. Education Committee: Extremism in schools: the Trojan Horse affair.

http://www.publications.parliament.uk/pa/cm201415/cmselect/cmeduc/473/473.pdf

Jarvis, L., and Lister, M. 2010. "Stakeholder security: the new western way of counterterrorism?" Contemporary Politics 16 (2): 173-188.

Joppke, C. 2009. Veil: mirror of identity. Cambridge: Polity.

Joppke, C. 2010. Citizenship and Immigration. Cambridge: Polity. 
Joppke, C. 2014. "The Retreat is Real - but what is the Alternative? Multiculturalism, Muscular Liberalism, and Islam." Constellations 21 (2): 286-295.

Joppke, C. and Torpey, J. 2013. Legal integration of Islam: a transatlantic comparison. Cambridge: Harvard University Press.

Koopmans, R. 2015. "Religious Fundamentalism and Hostility against Out-groups: A Comparison of Muslims and Christians in Western Europe." Journal of Ethnic and Migration Studies 41 (1): 33-57.

Klug, B. 2011. "An almost unbearable insecurity. Cameron's Munich speech." University of South Australia. Centre for Muslim and non-Muslim Understanding http://w3.unisa.edu.au/muslim-understanding/documents/klug-almost-unbearable.pdf

Lentin, A. and Titley, G. 2011. The Crises of Multiculturalism. Racism in a Neoliberal Age. London, Zed Books.

MacEoin, D. and Green, D.G. 2009. "Sharia Law or 'One Law for All'?" Civitas. http://www.civitas.org.uk/pdf/ShariaLawOrOneLawForAll.pdf

May, T. 2014. Speech to the Conservative Party Conference. http://goo.gl/782uJA

McGhee, D. 2010. Security, citizenship \& human rights: shared values in uncertain times. Basingstoke: Palgrave Macmillan.

Miah, S. 2014. "Trojan Horse, Ofsted and the 'Prevent'ing of Education." Discover Society. http://www.discoversociety.org/2014/07/01/trojan-horse-ofsted-and-the-preventing-ofeducation/

MCB 2007. "Meeting the needs of Muslim pupils in state schools. Information and guidance for schools." Muslim Council of Britain. http://www.religionlaw.co.uk/MCBschoolsreport07.pdf

Ofsted 2014a. "Letter to Ruby Kundi (Headteacher of Highfield Junior and Infant School)." Ofsted. http://www.birminghammail.co.uk/incoming/article7239266.ece/binary/Highfield\%20Jun ior\%20and\%20Infant\%20School\%200fsted\%20report

Ofsted 2014b. "Letter to Vanessa Frank (Gracelands Nursery School)." Ofsted. http://www.birminghammail.co.uk/incoming/article7239192.ece/binary/Gracelands\%20 Nursery\%20School\%200fsted\%20report

Ofsted 2014c. "Letter to A. Wilson (Interim Principal of Golden Hillock School)." Ofsted. http://www.goldenhillock.bham.sch.uk/images/ABOUT US/OFSTED/HMl\%20Monitoring\%20Visit \%2010\%20September\%202014.pdf

One Law for All. 2010. "Sharia law in Britain. A threat to one law for all \& equal rights." One law for all. http://www.onelawforall.org.uk/wp-content/uploads/New-Report-Sharia-Lawin-Britain_fixed.pdf 
Pickles, E. 2015. “Letter to Muslim Organisations.” http://t.co/14C0X500o5

Ragazzi, F. 2016. "Suspect community or suspect category? The impact of counter-terrorism as 'policed multiculturalism'." Journal of Ethnic and Migration Studies (online first): 1-18.

Stapleton, J. 1998. "James Fitzjames Stephen: liberalism, patriotism, and English liberty." Victorian Studies 41 (2): 243-263.

Stephen, J.F. 1862. “Liberalism.” Cornhill Magazine 5: 70-83.

Sørensen, E. 2006. "Metagovernance: The Changing Role of Politicians in Processes of Democratic Governance." The American Review of Public Administration 36 (1): 98-114.

Treitschke, H. 1880. “Ein Wort über unser Judenthum.” Preußische Jahrbücher 44-46: 1-33.

Van der Veer, P. 2001. Imperial encounters: religion and modernity in India and Britain. Princeton: Princeton University Press.

Waters, A. M. 2013. "Sharia law: extremism the Government ignores." Huffington Post, 12 February. http://www.huffingtonpost.co.uk/anne-marie-waters/sharia-law-extremismthe-_b_2668212.html

Wilshaw, M. 2014. "Letter to Michael Gove." The Guardian, 9 June. http://www.theguardian.com/education/2014/jun/09/trojan-horse-schools-wilshawofsted-gove 